\title{
The Relationship between Social Dominance Orientation and Religiosity mediated by Political Orientation and Race
}

\author{
David Bryan Oxendine \\ Department of Elementary Education, School of Education, University of North Carolina at \\ Pembroke \\ P. O. Box 1510, Pembroke, N. C. 28372, USA
}

Email: david.oxendine@ uncp.edu Tel: 1-910-521-6324

Received: April 28, 2018 Accepted: May 9, 2018 Published: June 21, 2018

doi:10.5296/iss.v5i2.13122 URL: http://dx.doi.org/10.5296/iss.v5i2.13122

\begin{abstract}
Political orientation and race have consistently found to be associated with social dominance orientation (SDO) and religiosity. This study explores the degree of influence that political orientation and race has on SDO and religiosity. The research participants consisted of 245 undergraduate and graduate students at an ethnically diverse regional university in the southeastern United States. As expected, Republican participants scored higher in SDO than Democrats, as White participants scored higher in SDO than did Non-White participants. Additionally, Republican participants scored higher in religiosity than did Democrats. As hypothesized, Non-Whites scored higher in religiosity than did Whites. Implications for future research on political orientation, race and other factors associated with SDO and religiosity.
\end{abstract}

Keywords: social dominance, religiosity, political orientation, race 


\section{Introduction}

The Charlottes ville protests in August 2017 included protesters such as Alt-Right, Ku Klux Klan, Nationalism, Neo-Nazis, and White Supremacists groups, resulting in the death of Heather Heyer. President Trump's response that there were good people on both sides of this issue raised many red flags concerning his true attitude toward minority issues. Abundant research reveals that conservative beliefs or those who identify as politically conservative are significantly related with higher levels of self-related prejudice or modern racist attitudes and beliefs toward minority or disadvantaged social groups (Costello \& Hodson, 2011; Crawford \& Pilanski, 2014; Crowson \& Brandes, 2017; Oxendine, 2016b; Webster, Burns, Pickering, \& Saucer, 2014). For decades social psychologists have found an abundance of empirical evidence linking the social, cognitive, and the motivational processes that perpetuate intergroup conflict (Cokley, Tran, Hall-Clark, Chapman, Bessa, Finley, \& Martinez, 2010; Grina, Bergh, Akami, \& Sidanius, 2016; Guimond, Dambrun, Michinov, \& Duarte, 2003; Pratto, Sidanius, Stallworth, \& Malle, 1994; Oxendine, 2016a, 2016b, 2017; Poteat \& Spanierman, 2010; Poteat \& Spanierman, 2012; Webster et al., 2014; Whitley, 1999; Whitley \& Kite, 2006).

Scholars studying human societies find their social structures tend to be group based according to a hierarchical schema. Eventually, these societies develop where the dominant groups, which tend to have greater positive social value become the in-group and those with less positive social value become the out-group (Akrami \& Ekehammar, 2006; Guimond et al, 2003; Oxendine, 2016a; Oxendine, 2016b; Oxendine, 2017; Pettigrew, 2017; Pratto, et al.1994; Sidanius \& Pratto, 1999; Sidanius, Pratto, \& Bobo, 1994; Snellman \& Ekehammar, 2000). Historically, these groups have been defined by "race, sex, nationality, ethnicity, religion, social class, region, skin color ... among others (Sidanius \& Pratto, 1999, p. 61).

Much research finds that a conservative political orientation is consistently positively correlated to SDO (Akrami \& Ekehammar, 2006; Guimond et al., 2003; Oxendine, 2016a; Oxendine, 2016b; Oxendine, 2017; Pettigrew, 2017; Pratto, et al.1994; Sidanius \& Pratto, 1999; Sidanius, Pratto, \& Bobo, 1994). Pettigrew (2017) found among the many factors that may comprise the psychological makeup of the general Trump supporter, social dominance orientation, religiousness, political orientation, and race are the major social psychological components that may explain this phenomenon.

\subsection{Social Dominance Orientation}

According to Pratto et al. (1994), social dominance orientation theory "postulates that societies minimize group conflict by creating consensus on ideologies that promote the superiority of one group over others" (p.741). For SDO to work, it is essential that ideologies maintain a sense of group inequality, thereby giving discrimination legitimacy. Societies accomplished this ensuring these ideologies are accepted throughout societies that some groups are superior to lesser inferior groups or hierarchy-legitimizing myths (Cokely et al.; Pratto et al.). Some of the hierarchy-legitimizing myths for this study are gender, ethnic or racial prejudice, and political-economic conservatism. Throughout the world, the hierarchy afforded to men and women seems to be consistent with men holding greater hierarchy 
enhancing attitudes and beliefs (Grina et al., 2016; Lindén, Björklund, \& Bäckström, 2016; Pratto et al., 1994; Sidanius \& Pratto, 1999; Sidanius et al., 1994). These findings suggest that males are more socially dominating than women. In the United States, ethnic or racial prejudice is one of the major ideologies when concerned with relative group hierarchy (Cokely et al., 2010; Crowson \& Brandes, 2017; Duckitt \& Sibley, 2007; Ho, Sidanius, Kteily, Sheehy-Skeffington, Pratto, Henkel, Foels, \& Stewart, 2015; Oxendine, 2016b; Pratto et al; Sidanius \& Pratto; Sibley \&Duckitt, 2008; Sibley, Robertson, \& Wilson, 2006; Umphress, Simmons, Boswell, \& Triana, 2008).

Research has demonstrated that SDO is an important predictor of attitudes toward racial and ethnic minorities as well as women's rights and has been consistently related to prejudicial attitudes and beliefs (Cokely et al., 2010; Duckitt \& Sibley, 2007; Grina et al., 2016; Guimond, Crisp, Oliveira, Kamiejski, Kteily, Kuepper, Lalonde, Levin, Pratto, Tougas, Sidanius, \& Zick, 2013; Ho, Sidanius, Pratto, Levin, Thomsen, Kteily, \& Sheehy-Skeffington, 2012; Ho et al., 2015Oxendine, 2016b; Pettigrew, 2017; Sibley \&Duckitt, 2008; Sibley, Robertson, \& Wilson, 2006).

Webster et al. (2014) suggest that individuals high in SDO operate from a Darwinian perspective, for they perceive that resources are limited. Therefore, they are highly motivated to behave in a manner that attempts to secure these resources for their in-group. The issue of capitalism versus socialism is usually the view that in capitalism some individuals and businesses should flourish greatly, while others should not, according to Pratto et al. This view is considered political-economic conservatism ideology and is a positively correlated hierarchy-enhancing legitimizing myth with SDO (Cokely et al., 2010; Duckitt \& Sibley, 2007; Grina et al.,; Oxendine, 2016b; Pratto et al.; Sidanius \& Pratto; Sibley \& Duckitt, 2008; Sibley, Robertson, \& Wilson, 2006).

\subsection{Religiosity}

It is well established in the social psychological literature that religious people are also likely to to be prejudiced, obviously with some exceptions (Allport \& Ross, 1967; Altemeyer, 2003). One would think that the very nature and many of the principles of religious thought concerning loving others, caring for those less fortunate, and striving for harmony among humanity one would not also find among its characteristics prejudice and bigotry. Much of the research is clear, there is a strong relationship among those who attend church the most are also likely to be prejudiced against many of those different from themselves on many levels (Altemeyer, 2003; Altemeyer \& Hunsberger, 1992; Altemeyer \& Hunsberger, 2004; Beller, 2017; Beller \& Kröger, 2017; Blogowska \& Saroglou, 2013; Brandt \& Van Tongeren, 2015; Jackson, 2011; Jackson \& Hunsberger, 1999; Laythe, Finkel, \& Kirkpatrick, 2001; Leak \& Finken, 2011; Rowatt, LaBouff, Johnson, Froese, \& Tsang, 2009; Silver \& Silver, 2017). Perhaps the very the nature of religion itself leads to these outcomes. All major cultures in the world have their specific religion. Therefore the nature of religious thought is that these beliefs are internalized as being the "only true belief," thereby creating the conflict between in-group and out-group believers. If one does not follow my "true belief," they are wrong, thereby, creating religious tribalism. 
Religious fundamentalism according to Altemeyer and Hunsberger (1992) is defined as

"...the belief that there is one set of religious teachings that clearly contains the fundamental, basic, intrinsic, essential, inerrant truth about humanity and deity; that this essential truth is fundamentally opposed by forces of evil which must be vigorously fought; that this truth must be followed today according to the fundamental, unchangeable practices of the past; and that those who believe and follow these fundamental teachings have a special relationship with the deity. (p. 118)

Based on this definition by Altemeyer and Hunsberger, it may not depend as much on what particular dogma and beliefs, but may be more indicative of the attitudes held by those with these particular beliefs (Altemeyer, 2003). In other words, these believers believe scripture is the "literal word of God," and any variation belief is sinful and wrong. According to Young, Willer, and Keltner (2013), those with a fundamentalist worldview held a more restrictive cognitive view of the world. When discussing topics such as life and death, these individuals had a limited perspective and relied on their strict literal interpretations of scripture.

\subsection{Political Orientation}

Political orientation and political ideologies for decades have investigated political conservatism and its relationship with social dominance orientation and race (Crawford \& Pilanski, 2014; Crowson \& Brandes, 2017; Dimdins, Sand gren, \& Montgomery, 2016; Grina et al., 2016; Ho et al, 2012; Laythe et al., 2001; Nail, Harter, \& Decker, 2003; Osborne, Wootton, \& Sibley, 2013; Oxendine, 2016b; Pratto et al., 1994; Sidanius \& Pratto, 1999). Social psychologists have shown that political orientation has a significant relationship with social dominance orientation (Grina et al.; Guimond et al., 2013; Ho et al.; Nail et al., 2003; Sidanius \& Pratto, 1999; Sidanius, Pratto, \& Bobo, 1996; Silver \& Silver, 2017).

Principled conservatism operates in a duality. Conservative Whites appear to support policies of racial equality and at the same time work in opposition of racial equality and seek to overturn these policies fitting nicely social dominance orientation (Cokely et al., 2010; Crawford \& Pilanski, 2014; Dimdins et al., 2016; Duckitt \& Sibley, 2007; Grina et al., 2015; Guimond et al., 2013; Ho et al., 2012; Oxendine, 2016b; Sidanius et al, 1996, Sniderman, Piazza, Tedlock, \& Kendrick, 1991). Sidanius et al. suggest that principled conservatism and political conservatives are related, for example, their resistance toward policies that have a positive impact for minorities, such as affirmative action are usually not motivated by racism per se. Conservatives generally oppose such policies simply because these are social policies in which conservatives object to simply as a matter of principle.

\subsection{Race}

Social psychologists and anthropologists have known and demonstrated empirically for decades that defining human beings as distinctive racial groups along physical and biological characteristics have no basis in fact, although still today a large majority of people in the United States think otherwise (Buffington, 2018; Smedley \& Smedley, 2005). In efforts to categorize humans along some cultural dimension outside of the scientific domain, differences among humans were created together with both physical characteristics and 
behavior. According to Smedley and Smedley (2005), the term race developed as a "folk idea" between the $16^{\text {th }}$ and the $18^{\text {th }}$ centuries in Europe used to describe the "type, kind, sort, breed, or species" of domesticated animals (p. 19). These notions concerning race found a stronghold in the early colonial United States, through the period of slavery, the reconstruction period, and continuing to the present time. Therefore, the term race as we know it was socially constructed as a means to categorize people to create a hierarchical social order based on physical and socio-economic dimensions.

Racism is a learned socially constructed cultural phenomenon that develops as early as the preschool years (Rothenberg, 2007). In the United States, White's as a group, continue to not really comprehend how widespread racial disparities that exist, simply because this is not a salient issue for them (Dhont, Van Hiel, \& Hewstone, 2014; Dovidio, Gaertner, Kawakami, \& Hodson, 2002; Oxendine, 2016a, 2016b; Utsey et al., 2008). Socially, the United States is still very much composed largely of segregated communities (Bakanic, 2009; Bryan, Wilson, Lewis, \& Willis, 2012; Cokely et al., 2010; Gallagher, 2011; Jackson, 2011; Jones, 2002; Nelson, 2006; Oxendine, 2016a, 2016b; Rothenberg, 2007; Smedley \& Smedley, 2005).

\subsection{The Current Study}

Previous research has demonstrated that individuals high in social dominance orientation tend to be White and Republican or conservative politically (Cokely et al.; Grina et al., 2016; Pratto et al., 1994; Sidanius \& Pratto, 1999; Sidanius et al., 1994). Additionally, studies have shown that individuals having strong religious fundamentalist beliefs tend to be White and Republican or conservative (Altemeyer, 2003; Altemeyer \& Hunsberger, 1992; Altemeyer \& Hunsberger, 2004; Blogowska \& Saroglou, 2013; Jackson \& Hunsberger, 1999; Leak \& Finken, 2011), however this study will attempt to demonstrate, based on the circumstances of this sample, the results will indicate that Non-White participants will show a stronger relationship with religiosity. Therefore, current study attempts to investigate the relationship impact between social dominance orientation and religiosity on dimensions of political orientation and race. For simplicity, this study utilizes the broader term "racial group" differentiated as White and Non-White.

\subsection{Hypotheses}

Hypothesis 1 states that there is a significant effect between social dominance orientation and political orientation (Republican). Hypothesis 2 states there is a significant effect between social dominance orientation and racial group (White). Hypothesis 3 states there is a significant effect between religiosity and political orientation (Republican). Hypothesis 4 states that there is a significant effect between religiosity and racial group (Non-White).

\section{Method}

\subsection{Participants}

Participants were 245 undergraduate and graduate college students (females 174=71\% and males $71=29 \%$ ) enrolled at a small southeastern university. As participants entered the classroom the first day of class they were informed of the study. An informed consent form 
was given explaining that participation in the study was voluntary and would not affect their grade in the course. The age range for the participants was as follows: $18-20=(n=47) 19.2 \%$, $21-23=(n=80) 32.7 \%, 24-26=(n=33) 15.9 \%, 27-29=(n=16) 6.5 \%$, and $30+=(n=69)$ $25.7 \%$.

\subsection{Political Orientation and Racial Group Membership}

Political orientation and racial group membership was obtained by having participants self-report their political orientation into these categories: Democrat $(n=104) 42.4 \%$, Republican $(n=58) 23.7 \%$, Independent $(n=24) 6.7 \%$, Other $(n=10) 4.1 \%$, and None $(n=49)$ $20.0 \%$. Participants self-reported their ethnicity as follows: American $\operatorname{Indian}^{1}(n=68) 27.8 \%$, Black $(n=41) 16.7 \%$, Hispanic $(n=4) 31.6 \%$, White $(n=125) 51 \%$, and those identified as Other $(n=7) 2.9 \%$. This sample is representative of the university population (White $=124$, $50.6 \%$; Non-White $=121,49.4 \%$ ).

\subsection{Measures}

SDO variables were measured with 14 item Social Dominance Orientation Scale (Pratto et al., 1994). The SDO scale is rated on a 7-point Likert-type scale with $1=$ Very Negative to $7=$ Very Positive, where higher scores indicate greater levels of social dominance. Item 8-14 are reversed scored. Reliability analysis using Cronbach's alpha for the current study yielded a coefficient of $.85(M=3.498, S D=1.278)$ consistent with Pratto el al.'s findings. See Table 1 .

Table 1. Social dominance orientation scale

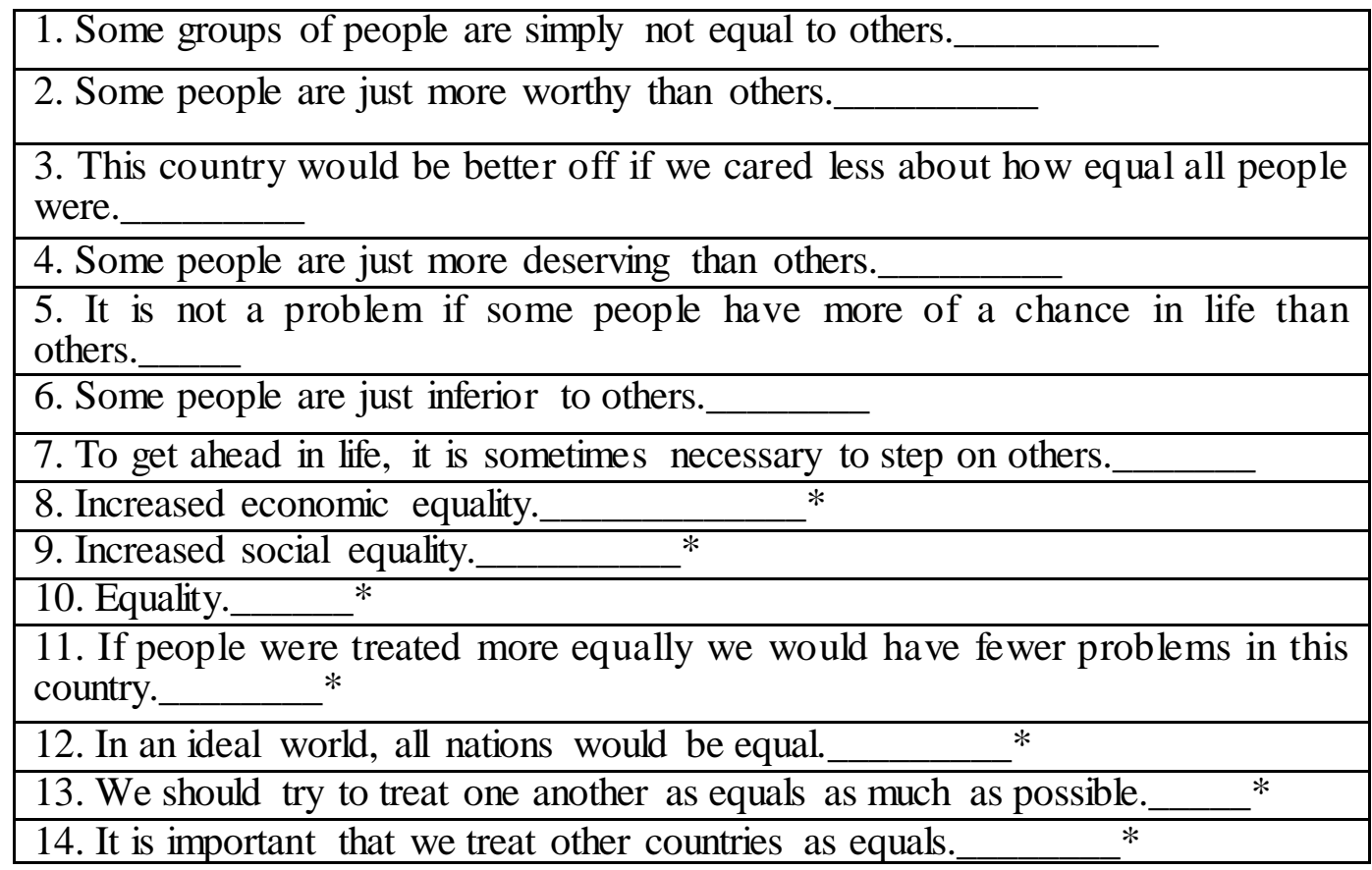

Note. $N=245$. Items scored on the following response choices ( $1=$ Very Negative-7=Very Positive. *Items 8-14 were reversed scored. Social Dominance Orientation Scale (SDO). 
Altemeyer \& Hunsberger (2004) revised their 20 item Religious Fundamentalism Scale (RFS) to 12 items to correct issues involving not capturing all of the aspects of fundamentalism as normally defined. The Religious Fundamentalism Scale is rated an 8-point Likert-type scale with $1=$ Very Strongly Disagree to $8=$ Very Strongly Agree. Reliability analysis using Cronbach's alpha for the current study yielded a coefficient of .91 $(\mathrm{M}=14.215, \mathrm{SD}=5.812)$ consistent with Altemeyer and Hunsberger's findings. See Table 2.

Table 2. Religious fundamentalism scale

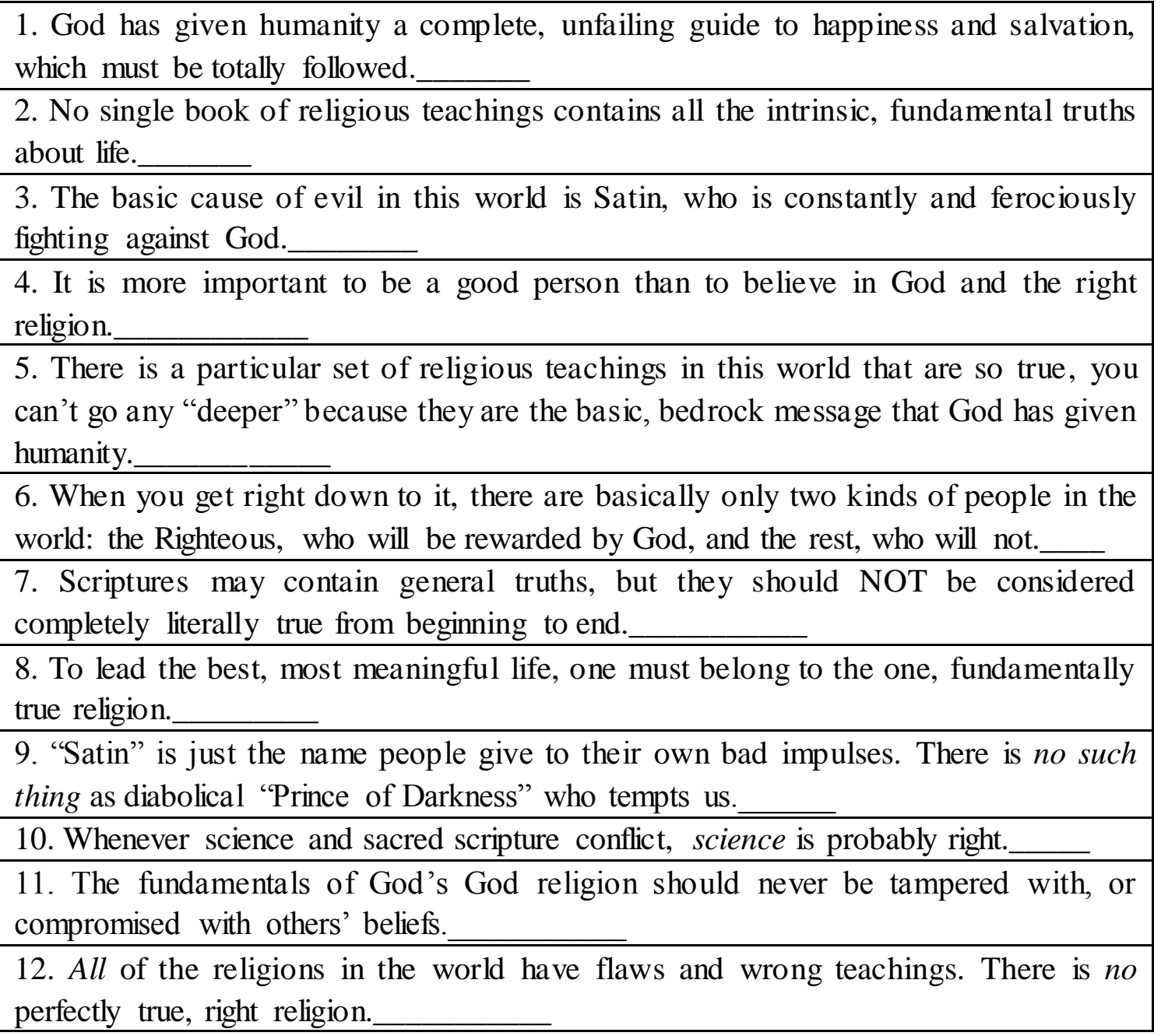

Note. $N=245$. Religious Fundamentalism Scale (RFS). Items scored on the following response choices $(1=$ Very Strongly Disagree-8=Very Strongly Agree.

\subsection{Procedures}

The first day of class students in the School of Education received an informed consent form and questionnaire packet. Respondents voluntarily completed the questionnaires without 


\section{Macrothink}

incentives. Debriefing of all participants concerning the nature of the study occurred followed after completion of the surveys.

\section{Results}

\subsection{Theoretical Predictions}

To test Hypothesis 1, and the relationship between social dominance orientation and political orientation utilizing a one-way ANOVA. The ANOVA revealed a significant result $F(4,240)$ $=2.646, p<.03, \mathrm{y}_{\mathrm{p}}{ }^{2}=.04$, which is a medium effect according to Cohen (1988). A closer look at the means and standard deviations of this relationship reveals Republicans $(M=2.755$, $S D=1.015)$ and Democrats $(M=2.399, S D=.856)$. Therefore, those participants that identified as Republican held significant greater levels of social dominance behavior, while Democrat participants reported the least levels of social dominance behavior, therefore, supporting hypothesis 1 . See Table 3.

To test Hypothesis 2, and the relationship between social dominance orientation and racial group by utilizing a one-way ANOVA. The ANOVA revealed a significant result $F(1,243)=$ $3.350, p<.04, \mathrm{y}_{\mathrm{p}}{ }^{2}=.02$, which is a small effect according to Cohen (1988 A closer look at this relationship reveals White group participants $(M=2.614, S D=.940)$ reported greater levels of social dominance behavior than did Non-White group participants $(M=2.380, S D$ $=.872$ ), therefore, supporting hypothesis 2 . See Table 3 .

Table 3. Political orientation \& racial group ANOVA means and standard deviations for social dominance orientation

\begin{tabular}{lllllll}
\hline Social Dominance Orientation & \multicolumn{2}{c}{ PO } & \multicolumn{2}{c}{ RG } & \\
& $M$ & $S D$ & $M$ & $S D$ & \\
\hline Republican & & & & & \\
Democrat & 2.755 & $(1.015)^{*}$ & 2.614 & $(.940)^{*}$ & White \\
& 2.399 & $(.856)$ & 2.380 & $(.872)$ & Non-White
\end{tabular}

Note. ${ }^{*} p<.05$ level. $N=245$. Items scored on the following response choices $(1=$ Very Negative-7 =Very Positive). Social Dominance Orientation Scale (SDO).

To test Hypothesis 3, and the relationship between religiosity and political orientation utilizing a one-way ANOVA. The ANOVA revealed a result $F(4,240)=4.924, p<.001, \mathrm{y}_{\mathrm{p}}{ }^{2}$ $=.08$, which is a large effect according to Cohen (1988These results indicated that Republicans $(M=5.783, S D=1.487)$ scored higher in religiosity than did Democrats $(M=$ 5.198, $S D=1.592$ ), therefore, supporting hypothesis 3. See Table 4.

To test Hypothesis 4, and the relationship between religiosity and racial group utilizing a one-way ANOVA. As expected, the ANOVA revealed a result $F(1,243)=7.981, p<.005$, 
$\mathrm{y}_{\mathrm{p}}{ }^{2}=.03$, which is a medium effect according to Cohen (1988). A closer look at the means and standard deviations of this relationship indicate Non-White participants $(M=5.462, S D=$ 1.589) scored higher in religiosity than did White participants $(M=4.843, S D=1.82)$, therefore, supporting hypothesis 4 . See Table 4.

Table 4. Political Orientation \& racial group ANOVA means and standard deviations for religiosity

\begin{tabular}{lcccccc}
\hline Religiosity & \multicolumn{2}{c}{ PO } & \multicolumn{3}{c}{ RG } & \\
& $M$ & $S D$ & 4.843 & $(1.827)$ & White \\
Republican & 5.783 & $(1.487)^{*}$ & & & \\
Democrat & 5.198 & $(1.592)$ & 5.462 & $(1.589)^{*}$ Non-White \\
& & & & & \\
\hline
\end{tabular}

Note. ${ }^{*} p<.05$ level. $N=245$. Items scored on the following response choices $(1=$ Very Strongly Disagree-8=Very Strongly Agree). Religious Fundamentalism Scale (RFS).

A follow-up two-way ANOVA was conducted to determine if Non-White participants scored higher in religiosity across political orientation. This analysis revealed a significant result $F(4$, $235)=3.109, p<.016, \mathrm{y}_{\mathrm{p}}{ }^{2}=.05$ for political orientation and a significant result $F(1,235)=$ $4.688, p<.031, \mathrm{y}_{\mathrm{p}}{ }^{2}=.02$ for racial group. These results indicate that Non-White participants scored higher in religiosity across political orientation; Democrat $(M=5.307, S D=1.517)$ and Republican $(M=6.09, S D=1.562)$.

\section{Discussion}

The purpose of this study was to examine the relationship between political orientation and race on social dominance orientation and religiosity. Among the leading definitions of social dominance orientation theory is that individuals, groups, and societies reduce societal conflict by developing a consensus on ideologies that create group inequality by promoting group superiority over lesser out-groups (Cokely et al., 2010; Duckitt \& Sibley, 2007; Grina et al., 2016; Ho et al., 2012; Pratto et al., 1994; Osborne et al., 2013; Oxendine, 2016b; Pettigrew, 2017; Sibley \&Duckitt, 2008; Sibley et al., 2006; Sidanius et al., 1996). SDO manifests politically on the Republican or conservative end of the spectrum (Pratto et al., 1994; Sidanius et al., 1994; Sidanius et al., 1996). Racially, those high in SDO tend to be White conservatives that oppose civil rights legislation, and other such social initiatives have developed an ideology that groups are unequal, therefore, they support policies that legitimize these myths (Grina et al., 2016; Ho et al., 2012; Pratto et al., 1994; Oxendine, 2016b; Pettigrew, 2017; Pratto et al., 1994; Sidanius et al., 1996). 
Previous research on religiosity has consistently found that groups or individuals scoring high in religiosity, or in other words, with a fundamentalist belief perspective tend to be politically republican or conservative (Altemeyer, 2003; Altemeyer \& Hunsberger, 1992; Altemeyer \& Hunsberger, 2004; Berller, 2017; Blogowska \& Saroglou, 2013; Jackson \& Hunsberger, 1999; Laythe et al., 2001; Leak \& Finken, 2011; Silver \& Silver, 2017). Similarly, research has shown that those high in religiosity tend to be racially White (Altemeyer, 2003; Altemeyer \& Hunsberger, 1992; Altemeyer \& Hunsberger, 2004; Berller, 2017; Duriez, \& Hutsebaut, 2000; Laythe et al.; Schaefer, 2015). According to Laythe et al., these individuals have a conservative political orientation that is an essential element of their fundamentalist belief system. The current study hypothesized that this particular sample, those individuals high in religiosity, would be Non-White.

Hypothesis 1 states that regarding political orientation, Republican participants would score significantly higher in social dominance oriented behavior, which was supported. According to Pratto et al. (1994), individuals or groups high in SDO regarding interpersonal relations prefers a hierarchical trajectory. In other words, they view the social order along a superior-inferior status in which their in-group is dominant to all other out-groups (Akrami \& Ekehammar, 2006;Cokely et al., 2010; Crawford \& Pilanski, 2014; Duckitt \& Sibley, 2007; Grina, et al., 2016; Ho et al., 2012; Ho et al., 2015; Oxendine, 2016a; Oxendine, 2016b; Oxendine, 2017; Pettigrew, 2017; Sibley \&Duckitt, 2008; Sibley et al., 2006). Numerous researchers have established the relationship between, social class, political conservatism, racism, and authoritarianism all incorporating the basic tenets of SDO, legitimizing the myths of ethnic and cultural superiority of the dominant in-group over the lesser out-group (Akrami \& Ekehammar, 2006;Cokely et al., 2010; Ho et al., 2012; Ho et al., 2015; Oxendine, 2016a; Oxendine, 2016b; Oxendine, 2017; Pettigrew, 2017).

Hypothesis 2 states that White participants would score significantly higher in social dominance oriented behavior, which was supported. The social psychological literature is replete with empirical evidence supporting the notion of triangulation of political conservatism, prejudice, and the dominant ethnic culture (White) as core components of social dominance orientation theory (Akrami \& Ekehammar, 2006; Cokley et al., 2010; Guimond et al., 2003; Oxendine, 2016a; Oxendine, 2016b; Oxendine, 2017; Pratto et al., 1994; Poteat \& Spanierman, 2010; Poteat \& Spanierman, 2012). Oxendine (2017) found this to be the case among academic college majors, whereby, School of Business majors held greater levels of modern racism attitudes and beliefs than did other academic majors. The core common denominator being a significant majority of Whites that were politically conservative.

Hypothesis 3 states that regarding political orientation, Republican participants would score significantly higher in religiosity, which was supported. This result is supported by previous empirical evidence suggesting that individuals high in religious fundamentalism beliefs tend to be Republican or conservative politically (Altemeyer, 2003; Altemeyer \& Hunsberger, 1992; Altemeyer \& Hunsberger, 2004; Berller, 2017; Blogowska \& Saroglou, 2013; Crawford \& Pilanski, 2014; Jackson \& Hunsberger, 1999; Laythe et al., 2001; Leak \& Finken, 2011; Rowatt et al., 2009; Silver \& Silver, 2017). Laythe et al. suggest that conservative 
political ideology is central to the religious fundamentalist belief system. In other words, religious fundamentalists follow a strict set of dogma with a literal interpretation of the Bible as "literary true," and the "literal word of God" and any variation away from this interpretation is sinful and a threat to eternal salvation (Altemeyer \& Hunsberger, 1992; Beller, 2017; Beller \& Kröger, 2017; Blogowska \& Saroglou, 2013; Silver \& Silver, 2017); with implications for militancy (Beller \& Kröger, 2017). Whereas, political conservatives tend to be against economic redistribution of wealth, social programs while supporting the status quo of maintaining religious values and strong advocates for the military. Additionally, political conservatives, like religious fundamentalists are more inclined to seek to ensure order in the world, strive for cognitive closure, having a low tolerance for ambiguity (Young et al., 2013, p. 112).

Hypothesis 4 states that there is a significant effect between religiosity and racial group (Non-White), which was supported. Normally, one might expect the result to be White participants to score higher in religiosity than Non-Whites. Specific characteristics of the sociohistorical environmental conditions of the sample may help explain this hypothesis and result. The sample was drawn from the "Bible Belt" in the southeastern corner of North Carolina where approximately $49.4 \%$ of the sample was composed of Lumbee American Indian and Black participants. According to Oxendine (1995; 2004), these populations have historically been subjected to prejudice and discrimination in addition to the entire area is economically depressed still today (Sider, 2003).

A convincingly plausible explanation for this result could be Agnew's general strain theory (GST) (as cited in Rocque, 2008), it demonstrates how sociohistorical environmental conditions are resulting in stress or strain influences behavior. For example, varying degrees of harsh treatment resulting from prejudice and discrimination historically for Lumbee American Indians and the devastating impact of slavery and its long-term aftermath for Blacks, these populations found religion and spirituality offered a meaningful and effective way of coping and managing GST (p. 256). Therefore, GST could provide a reasonable explanation for Non-Whites in this study for scoring high in religiosity.

\subsection{Limitations and Future Research}

As with all studies, there are methodological limitations which may limit conclusions drawn from this study. One obvious limitation is this was a sample of convenience. Although this study drew from a population of university undergraduate and graduate students, it did have an advantage of including non-traditional age students which offer an age-related experiential variety which aids generalizability and external validity of the results.

Another possible limitation of this study may be an apparent unrealistic racial group component of this sample as compared with the average population. This sample was composed of White $=124,50.6 \%$; Non-White $=121$, 49.4\%. In other words, 68 identified as Lumbee American Indian and 41 identified as Black, meaning 109 of the total sample of 245 were Lumbee and Black. The university from which this sample came is unique in its own right. This university began in 1887 as an American Indian Normal School to teach American Indians to become teachers. From the 1940s until 1953 this university was the only state, 
supported four-year American Indian serving college in the United States (Dial, 1993; Dial \& Eliades, 1996; Oxendine, 1995; Oxendine, 2004; Oxendine, 2016b; Oxendine \& Nacoste, 2007; Sider, 2003). Therefore, this university and region have a long and storied history of tri-racial (Lumbee American Indian, Black, and White) intergroup contact creating a sociohistorical environmental context leading to intergroup tensions for over 250 years, according to Dial and Eliades.

Additionally, another possible limitation of this study could be collapsing racial groups into only two categories, White and Non-White. It is clear there exists both between group and within group differences among all racial and ethnic groups. Although this procedure was conducted for parsimony across data, the results garnered from this study suggest that valuable and valid empirical data was found. Future research should investigate how SDO and religiosity are mediated across political orientation and race with a sample more normally distributed as the general population. With a normally distributed population across race, White participants should score higher in religiosity than in the present study. Future studies should also investigate possible gender differences within aspects of SDO and religiosity across political orientation and race. Another area of investigation could be the relationship between SDO and religiosity as mediated by modern racism attitudes and beliefs.

The present study explores the relationship between political orientation and race as a function of social dominance orientation and religiosity. The results of this study support previous research finding significant relationships between SDO and religiosity as mediated by political orientation and race. Studies of this type are vitally important in the future as we approach new presidential, gubernatorial, congressional, and state-wide elections where political orientation and race will continue to influence issues of social dominance and religiosity, which no doubt impact the outcome of future elections.

\section{Acknowledgment}

Dr. David B. Oxendine, Associate Professor, Department of Elementary Education, School of Education, Univiersity of North Carolina at Pembroke. Correspondence concetrning this article should be addressed to Dr. David B. Oxendine, Associate Professor, Department of Elementary Education, School of Education, Univiersity of North Carolina at Pembroke, P. o. Box 1510, Pembroke, N. C. 28372. Email: david.oxendine@ uncp.edu.

\section{References}

Akrami, A. \& Ekehammar, B. (2006). Right-wing authoritarianism and social dominance orientation. Their roots in big-five personality factors and facets. Journal of Individual Differences, 27(3), 117-126. http://dx.doi.org/10.1027/1614-0001.27.3.117

Allport, G. W., \& Ross, J. M. (1967). Personal religious orientations and prejudice. Journal of Personality and Social Psychology, 5, 432-443. https://doi.org/10.1037/h0021212

Altemeyer, B. (2003). Why do religious fundamentalists tend to be prejudiced? The International Journal for the Psychology of Religion, 13(1), 17-28. https://doi.org/10.1207 /S15327582IJPR1301_03 
Altemeyer, B., \& Hunsberger, B. (2004). A revised religious fundamentalism scale: The short and the sweet of it. International Journal for the Psychology of Religion, 14, 47-54. https://doi.org/10.1207/s15327582ijpr020_5

Bakanic, V. (2009). Prejudice: Attitudes about race, class, and gender. New Jersey: Pearson.

Beller, J. (2017). Religion and militarism: The effects of religiosity, religious fundamentalism, religious conspiracy belief, and demographics on support for military action. Peace and Conflict; Journal of Peace Psychology, 23(2), 179-182. http://dx.doi.org/10.1037 /pac0000250

Beller, J., \& Kröger, C. (2017). Is religious fundamentalism a dimensional or a categorical phenomenon? A taxometric analysis in two samples of youth from Egypt and Saudi Arabia. Psychology of Religion and Spirituality, 9(2), 158-164. http//dx.doi.org/10.1037/re10000 085

Blogowska, J., \& Saroglou, V. (2013). For better or worse: Fundamentalists' attitudes toward outgroups as a function of exposure to authoritative religious texts. The International Journal for the Psychology of Religion, 23, 103-125. https://doi.org/10.1080 /87567555.2012.687991

Brandt, M. J., \& Van Tongeren, D. R. (2015). People both high and low religious fundamentalism are prejudiced toward dissimilar groups. Journal of Personality and Social Psychology, 112(1), 76-97. http://dx.doi.org/10.1037/pspp0000076

Buffington, D. (2018). Blacks are naturally good athletes. The myth of a biological basis for race. In S. M. McClure \& C. Harris (Eds.), Getting real about race (2 ${ }^{\text {nd }}$ ed.), (pp. 14-24). Los Angeles: Sage.

Cohen, J. (1988). Statistical power analysis for the behavioral sciences $\left(2^{\text {nd }}\right.$ ed.). New Jersey: Lawrence Erlbaum Publishers.

Cokley, K. O., Tran, K., Hall-Clark, B., Chapman, C., Bessa, L., Finley, A., \& Martinez, M. (2010). Predicting student attitudes about racial diversity and gender equity. Journal of Diversity in Higher Education, 3(3), 187-199. https://doi.org/10.1037/a0020467

Costello, K., \& Hodson, G. (2011). Social dominance-based threat reactions to immigrants in need of assistance. European Journal of Social Psychology, 41, 220-231. https://doi.org/ 10.1002/ejsp.769

Crawford, J. T., \& Pilanski, J. M. (2014). The differential effects of right-wing authoritarianism and social dominance orientation on political intolerance. Political Psychology, 35(4), 587-576. https://doi.org/10.1111/pops. 12066

Crowson, H. M. \& Brandes, J. A. (2017). Differentiating between Donald Trump and Hillary Clinton voters using facets of right-wing authoritarianism and social dominance orientation: A brief report. Psychological Reports, 120(3), 364-373. https://doi.org /10.1177/0033294117697089 


\section{Mll Macrothink}

Issues in Social Science

ISSN 2329-521X

2018, Vol. 6, No. 1

Dhont, K., Van Hiel, A., \& Hewstone, M. (2014). Changing the ideological roots of prejudice: Longitudinal effects of ethnic intergroup contact on social dominance orientation. Group Processes \& Intergroup Relations, 17(1), 27-44. https://doi.org/10.1177/13684302 13497064

Dial, A. L. (1993). The Lumbee: Indians of North America series. New York: Chelsea House.

Dial, A. L., \& Eliades, D. K. (1996). The only land I know: A history of theLumbee Indians. San Francisco: Indian Historian Press.

Dimdins, G., Sandgren, M., \& Montgomery, H. (2016). Psychological variables underlying political orientation in an old and a new democracy: a comparative study between Sweden and Latvia. Scandinavian Journal of Psychology, 57, 437-445. https://doi.org/10.1111 /sjop. 12414

Duckitt, J., Bizumic, B., Krauss, S. W., \& Heled, E. (2010). A tripartite approach to right-wing authoritarianism-conservatism-traditional model. Political Psychology, 31(5), 685-715. https://doi.org/10.1111/j.1467-9221.2010.00781.x

Duckitt, J., \& Sibley, C. G. (2007) Right wing authoritarianism and social dominance orientation and the dimensions of generalized prejudice. European Journal of Personality, 21, 113-130. https://doi.org/10.1002/per.614

Duriez, B., \& Hutsebaut, D. (2000). The relation between religion and racism: The role post-critical beliefs. Mental Health, Religion, \& Culture, 3(1), 85-102. https://doi.org/ 10.1080/13674670050002135

Grina, J., Akrami, N., \& Sidanius, J. (2016). Political orientation and dominance: Are people on the political right more dominant? Personality and Individual Differences, 94, 113-117. http://dx.doi.org/10.1016/j.paid.2016.01.015

Guimond, S., Crisp, R. J., Oliveira, P. D., Kamiejski, R., Kteily, N., Kuepper, B., Lalonde, R. N., Levin, S., Pratto, F., Tougas, F., Sidanius, J., \& Zick, A. (2013). Diversity policy, social dominance, and intergroup relations: Predicting prejudice in changing social and political contexts. Journal of Personality and Social Psychology, 104(6), 941-958. https://doi.org/10.1037/a0032069 http://dx.doi.org/10.1037/a0032069

Guimond, S., Dambrun, M., Michinov, N., \& Duarte, S. (2003). Does social dominance generate prejudice? Integrating individual and contextual determinants of intergroup cognitions. Journal of Personality and Social Psychology, 84(4), 697-721. https://doi.org/ 10.1037/0022-3514.84.4.697 http://dx.doi.org/10.1037/0022-3514.84.4.697

Ho, A. K., Sidanius, J., Pratto, F., Levin, S., Thomsen, L., Kteily, N., \& Sheehy-Skeffington, J. (2012). Social dominance orientation: Revisiting the structure and function of a variable predicting social and political attitudes. Personality and Social Psychology Bulletin, 38(5), 583-606. https://doi.org/10117/0146167211432765

Ho, A. K., Sidanius, J., Kteily, N., Sheehy-Skeffington, J., Pratto, F., Henkel, K. E., Foels, R., \& Stewart, A. L. (2015). The nature of social dominance orientation: Theorizing and measuring preferences for intergroup inequality using the new $\mathrm{SDO}_{7}$ Scale. Journal of 
Personality and Social Psychology, 109(6), 1003-1028. http://dx.doi.org/10.1037/pspi000 0033

Hodson, G. \& Costello, K. (2007). Interpersonal disgust, ideological orientations, and dehumanization as predictors of intergroup attitudes. Psychological Science, 18(8), 691-698. https://doi.org/10.1111/j.1467-9280.2007.01962.x

Hodson, G., \& Esses, V. M. (2005). Lay perceptions of ethnic prejudice: Causes, solutions, and individual differences. European Journal of Social Psychology, 35, 329-344. https://doi.org/10.1002/ejsp.251

Jackson, L. M. (2011). The psychology of prejudice: From attitudes to social action. Washington, D. C.: American Psychological Association.

Jackson, L. M, Hunsberger, B. (1999). An intergroup perspective on religion and prejudice. Journal for the Scientific Study of Religion, 38(4), 509-523. https://doi.org/10.2307/1387609

Laythe, B., Finkel, D., \& Kirkpatrick, L. A. (2001). Predicting prejudice from religious fundamentalism and right-wing authoritarianism: A multiple-regression approach. Journal for the Scientific Study of Religion, 40(1), 1-10. https://doi.org/10.1111 /0021-8294.00033

Leak, G. K., \& Finken, L. L. (2011). The relationship between the constructs of religiousness and prejudice: A structural equation model analysis. The International Journal for the Psychology of Religion, 21, 43-62. https $/ / d o i . o r g / 10.1080 / 10508619.2011 .532448$

Lindén, M., Björklund, F., \& Bäckström, M. (2016). What makes authoritarian and socially dominant people more positive to using torture in the war on terrorism? Personality and Individual Differences, 91, 98-101. http://dx.doi.org/10.1016/j.paid.2015.11.085

Nail, P. R., Harton, H. C., \& Decker, B. P. (2003). Political Orientation and modern versus aversive racism: Tests of Dovidio and Gaertner's (1998) integrated model. Journal of Personality and Social Psychology, 84(4), 754-770. http://dx.doi.org/10.1037/0022-3514.84. 4.754 PMid:12703647

Nelson, T. D. (2006). The psychology of prejudice (2 ${ }^{\text {nd }}$ ed.). New York: Pearson.

Osborne, D., Wootton, L. W., \& Sibley, C. G. (2013). Are liberals agreeable or not? Politeness and compassion differentially predict political conservatism via distinct ideologies. Social Psychology, 44(5), 354-360. https://doi.org/10.1027/1864-9335/a000132

Oxendine, D. (1995). Racial identity development among Lumbee American Indian college students on a predominately White campus. Unpublished master's thesis, North Carolina State University, Raleigh.

Oxendine, D. B. (2004). The effects of social exclusion threat and justifications on perceived fairness of an ethnic validation procedure: Implications for Lumbee Federal Recognition. (Doctoral dissertation, North Carolina State University, 2004). Dissertation Abstracts International, (UMI No. 3154343). 
Oxendine, D. B. (2016a). Gender, race, and college major: Do they predict modern racism? Journal of Social Science Studies, 3(2), 90-102. https://doi.org/10.5296 /jsss.v3i2.8835

Oxendine, D. B. (2016b). The relationship between political orientation and race on modern racism. Journal of Social Science Studies, 3(1), 67-82. https://doi.org/10.5296 /jsss.v3i1.7933

Oxendine, D. B. (2017). College major and modern racism: A matter of moral hypocrisy? Issues in Social Science, 5(2), 1-12. doi: 10.5296/iss.v5i2.11439

Oxendine, D. B. \& Nacoste, R. W. (2007). Who would claim to be that, who was not?: Evaluations of an ethnic validation procedure. Journal of Applied Social Psychology, 37(7), 1594-1629. https://doi.org/10.1111/j.1559-1816.2007.00229.x

Pettigrew, T. F. (2017). Social psychological perspectives on Trump supporters. Journal of Social and Political Psychology, 5(1), 107-116. https://doi.org/10.5964/jspp.v5i7.750

Poteat, V. P., Spanierman, L. B. (2010). Do the ideological beliefs of peers predict the prejudiced attitudes of other individuals in the group? Group Processes \& Intergroup Relations, 13(4), 495-514. https://doi.org/10.1177/1368430209357436

Poteat, V. P., \& Spanierman, L. B. (2012). Modern racism attitudes among White students: The role of dominance and authoritarianism and the mediating effects of racial color-blindness. The Journal of Social Psychology, 152(6, 758-774. https://doi.org /10.1080/00224545.2012.700966

Pratto, F., Sidanius, J., Stallworth, L. M., \& Malle, B. F. (1994). Social dominance orientation: A personality variable predicting social and political attitudes. Journal of Personality and Social Psychology, 67(4), 741-763. https://doi.org/10.1037/0022-3 514.67.4.741

Rocque, M. (2008). Strain, coping mechanisms, and slavery: A general strain theory application. Crime, Law, and Social Change, 49(4), 245-269. https://doi.org/10.1007 /s10611-008-9106-8

Rowatt, W. C., LaBouff, J., Johnson, M., Froese, P., \& Tsang, J. (2009). Associations among religiousness, social attitudes, and prejudice in a national random sample of American adults. Psychology of Religion and Spirituality, 1(1), 14-24. https://doi.org/10.1037 /a0014989

Schaefer, R. T. (2015). Racial and Ethnic Groups (14 ${ }^{\text {th }}$ ed.) Boston: Pearson.

Sibley, C. \& Duckitt, J. (2008). Personality and prejudice: A meta-analysis and theoretical review. Personality and Social Psychology Review, 12, 248-279. https://doi.org/10.1177/1088868308319226

Sibley, G., Robertson, A., \& Wilson, M. S. (2006). Social dominance orientation right-wing authoritarianism: Additive and interactive effects. Political Psychology, 27, 755-768. https://doi.org/10.1111/j.1467-9221.2006.00531.x

Sidanius, J. \& Pratto, F. (1999). Social Dominance: An Intergroup Theory of Social Hierarchy and Oppression. Cambridge, U. K.: Cambridge University Press. 
Sidanius, J., Pratto, F., \& Bobo, L. (1994). Social dominance orientation and the political psychology of gender: A case of invariance? Journal of Personality and Social Psychology, 67(6), 998-1011. https://doi.org/10.1037/0022-3514.67.6.998

Sidanius, J., Pratto, F., \& Bobo, L. (1996). Racism, conservatism, affirmative action, and intellectual sophistication: A matter of principled conservatism or group dominance? Journal of Personality and Social Psychology, 70(3), 476-490.http://dx.doi.org/10.1037/0022 $-3514.70 .3 .476$

Sider, G. M. (2003). Living Indian histories: Lumbee and Tuscarora people in North Carolina. Chapel Hill, NC: University of North Carolina Press.

Silver, J. R., \& Silver, E. (2017). Why are conservatives more punitive than liberals? A moral foundations approach. Law and Human Behavior, 41(3), 258-272. http:// dx.doi.org/10.1037/lhb0000232

Smedley, A., \& Smedley, B. D. (2005). Race as biology is fiction, racism as a social problem is real. Anthological and historical perspectives on the social construction of race. American Psychologist, 60(1), 16-26. https://doi.org/10.1037/0003-066x.60.1.16

Snellman, A. \& Ekehammar, B. (2005). Ethnic hierarchies, ethnic prejudice, and social dominance orientation. Journal of Community \& Applied Social Psychology, 15, 83-94. http://dx.doi.org/10.1002/casp.812

Sniderman, P. M., Piazza, T., Tetlock, P. E., \& Kendrick, A. (1991). The new racism. American Journal of Political Science, 35(2), 423-447. http//dx.doi.org/10.2307/2111369

Webster, R. J., Burns, M. D., Pickering, M., \& Saucer, D. A. (2014). The suppression and justification of prejudice as a function of political orientation. European Journal of Personality, 28, 44-59. doi: 10.1002/per.1896

Whitley, B. E., Jr. (1999). Right-wing authoritarianism, social dominance orientation, and prejudice. Journal of Personality and Social Psychology, 77(1), 126-134. http://dx.doi.org /10.1037/0022-3514.77.1.126

Whitley, B. E., Jr., \& Kite, M. E. (2006). The psychology of prejudice and discrimination. CA: Thomson Wadsworth.

Wilkins, D. E. (2002). American Indian politics and the American political system. New York: Rowman \& Littlefield.

Umphress, E. E., Simmons, A. L., Boswell, W. R., \& Triana, M. d. C. (2008). Managing discrimination in selection: The influence of directives from an authority and social dominance orientation. Journal of Applied Psychology, 93(5), 982-993. https://doi.org/ 10.1037/0021-9010.93.5982

Young, O. A., Willer, R., \& Keltner, D. (2013). "Thou shalt not kill": religious fundamentalism, conservatism, and rule-based moral processing. Psychology of Religion and Spirituality, 5(2), 110-115. https://doi.org/10.1037/a0032262 
Note

Note 1. Throughout this paper, the term American Indian is used to indicate indigenous peoples of North America. The term Native American is incorrect in that all peoples born on the North American continent could be considered Native American (Oxendine, 2017; Oxendine \& Nacoste, 2007; Wilkins, 2002).

\section{Copyright Disclaimer}

Copyright for this article is retained by the author(s), with first publication rights granted to the journal.

This is an open-access article distributed under the terms and conditions of the Creative Commons Attribution license (http://creativecommons.org/licenses/by/3.0/). 